\title{
EFEKTIVITAS JUMLAH TELUR Corcyra cephalonica TERPARASITASI Trichogramma sp. TERHADAP PRESENTASI TELUR YANG TERPARASIT DAN JUMLAH LARVA PENGGEREK BATANG TEBU BERGARIS (Chilo sacchariphagus)
}

\section{EFFECTIVENESS OF EGGS NUMBER OF Corcyra cephalonica PARASITED BY Trichogramma sp. ON PARASITED EGGS PERCENTAGE AND LARVAE NUMBER OF STRIPED CANE STEM BORER (Chilo sacchariphagus)}

\author{
Yati Setiati, Neneng Hayatul Mutmainah, M. Subandi \\ Jurusan Agroteknologi Fakultas Sains dan Teknologi UIN SGD Bandung \\ Korespondensi: yati.setiati@ymail.com
}

Diterima 14 Juli 2016 / Disetujui 22 Juli 2016

\begin{abstract}
ABSTRAK
Hama penggerek batang merupakan hama yang paling penting pada tanaman tebu. Penelitian ini bertujuan untuk mengetahui pengaruh telur Corcyra cephalonica yang terparasitasi Trichogramma sp. terhadap hama penggerek batang tebu bergaris (Chilo sacchariphagus). Serta untuk mengetahui jumlah telur Corcyra cephalonica yang terparasitasi Trichogramma sp. yang paling efektif terhadap pengendalian hama penggerek batang tebu bergaris (Chilo sacchariphagus) Penelitian ini dilaksanakan di PT. PG Rajawali II Unit Puslit Agro (pusat penelitian Agronomi) Desa Sumber Jatitujuh-Majalengka, dari bulan April sampai bulan Juni 2015. Hasil penelitian menunjukan bahwa pada parasitasi penggerek batang tebu bergaris (Chilo saccaripagus) perlakuan 5 pias (750 butir telur Trichogamma sp.) memiliki jumlah larva terendah rata-rata 4,33 larva dengan persentasi telur yang terparasit $92,23 \%$.
\end{abstract}

Kata kunci : Chilo saccaripagus, Corcyra cephalonica, Trichogramma sp.

\begin{abstract}
Stem borer is the most important pest in sugarcane. This study aimed to determine the effect of Corcyra cephalonica eggs which were parasited by Trichogramma sp. On striped cane stem borer (Chilo sacchariphagus). As well as to determine the number of eggs of Corcyra cephalonica parasited by Trichogramma sp. The research was conducted at PT. PG Rajawali II Unit Center for Agro (Agronomy research centers) Sumber Jatitujuh Village Majalengka, from April to June 2015. The result showed that in parasitism of striped cane stem borer (Chilo saccaripagus) treatment of 5 "pias" (750 eggs of Trichogamma sp.) had the lowest number of larvae on average 4,33 larvae with parasited eggs percentage of 92,23\%.
\end{abstract}

Keywords : Chilo saccaripagus, Corcyra cephalonica, Trichogramma sp.

\section{PENDAHULUAN}

Kebutuhan gula di Indonesia selalu meningkat dari tahun ke tahun dan hingga saat ini belum terpenuhi oleh produksi dalam negeri (Hafsah, 2002), oleh karena itu diperlukan upaya peningkatan produksi gula nasional secara optimal. Budidaya tanaman 
tebu yang merupakan faktor kunci penentu produksi gula harus terus menerus diperbaiki. Salah satu kendala dalam budidaya tebu adalah adanya serangan hama penggerek batang tebu (Ganeshan, 2001; Sunaryo, 2003). Penggerek batang tebu Chilo saccahariphagus (Lepidoptera) adalah salah satu hama yang berbahaya pada tanaman tebu. Hama ini menyerang tanaman tebu sejak dari awal tanaman sampai panen. Populasi larva Chilo sacchariphagus mulai meningkat dari umur tanaman 1,5 bulan dan mencapai puncaknya pada saat tanaman berumur 9,5 bulan. Serangan hama ini dapat menimbulkan kerugian mencapai 30\%-45\% (Meidalima et al., 2012).

Penelitian dilakukan untuk melihat respon pengendalian hama secara hayati menggunakan musuh alami yaitu parasitoid Trichogramma sp. yang memiliki beberapa keuntungan diantaranya dapat mencegah pencemaran lingkungan oleh bahan kimia dari insektisida, efisien, berkelanjutan, tidak merusak keragaman hayati, dan kompatibel dengan cara pengendalian lainnya (Kartohardjono, 2011).

Penggunaan Trichogramma sp. sebagai parasitoid telur diantaranya dapat dilakukan secara inundatif. Pada teknik inundatif adalah pelepasan musuh alami pada saat kritis, seperti halnya dengan penggunaan pestisida. Sehingga diperlukan teknik pembiakan alternatif yang tepat waktu, murah, dan mudah. Tepat waktu, perbanyakan dapat dibuat secara terjadwal sehingga tersedia sepanjang waktu. Mudah, dalam arti bahwa perbanyakan Trichogramma sp. dapat dilakukan dengan metode sederhana antara lain dengan menggunakan inang alternatif. Murah, bahwa makanan serangga inang alternatif mudah didapatkan serta dengan harga yang terjangkau. Perbanyakan Trichogramma sp. ini biasanya digunakan inang alternatif, yaitu telur serangga gudang Corcyra cephalonica yang dapat tersedia sepanjang waktu.

Trichogramma sp. betina akan menyimpan telur-telur mereka di dalam telur Corcyra cephalonica yang menjadi inang. Trichogramma sp. muda akan segera menetas dan memakan cairan tubuh inang di dalam telur inang, sehingga membunuh inang tersebut (Buchori et al.,2010).

\section{BAHAN DAN METODE}

Penelitian ini dilaksanakan di PT. PG Rajawali II Unit Puslit Agro (Pusat Penelitian Agronomi) Desa Sumber Kecamatan Jatitujuh Kabupaten Majalengka, Jawa Barat. Pelaksanaan penelitian dilaksanaan dari bulan April-Juni 2015.

Bahan yang digunakan dalam penelitian ini adalah :

- Telur Corcyra cephalonica (telur Chilo sacchariphagus yang berumur 1 hari setelah penggerek batang bertelur)

- Pias telur Corcyra cephalonica yang terparasitasi Trichogramma sp. Berumur 1 hari setelah terparasitasi

- Tanaman tebu yang berusia 5-7 bulan setelah tanam.

Rancangan percobaan yang akan dilakukan menggunakan Rancangan Acak Lengkap (RAL) satu faktor yang terdiri atas enam perlakuan, diantranya:

$P_{1}=1$ Pias (dengan jumlah telur 150 Corcyra cephalonica yang terparasit Trichogrammasp. dengan Chilo sacchariphagus)

$\mathrm{P}_{2}=2$ Pias (dengan jumlah telur 300 Corcyra cephalonica yang terparasit 
Trichogrammasp. dengan Chilo sacchariphagus)

$\mathrm{P}_{3}=3$ Pias (dengan jumlah telur 450 Corcyra cephalonica yang terparasit Trichogrammasp. dengan Chilo sacchariphagus)

$\mathrm{P}_{4}=4$ Pias (dengan jumlah telur 600 Corcyra cephalonica yang terparasit Trichogrammasp. dengan Chilo sacchariphagus)

$\mathrm{P}_{5}=5$ Pias (dengan jumlah telur 750 Corcyra cephalonica yang terparasit Trichogrammasp. dengan Chilo sacchariphagus)

$\mathrm{P}_{6}=6$ Pias (dengan jumlah telur 900 Corcyra cephalonica yang terparasit Trichogrammasp. dengan Chilo sacchariphagus).

Parameter pengamatan dalam penelitian ini, diantaranya:

1) Persentasi telur penggerek batang Terparasitasi (\%)

Persentasi terparasitasi diamati dengan menghitung parasitasi mulai dilakukan \pm enam hari setelah aplikasi, kemudian dihitung jumlah telur yang terparasit dengan menggunakan rumus sebagai berikut:

$\mathrm{P}=\frac{A}{B} x 100 \%$

Ket:

$\mathrm{P}=$ Persentasi terparasitasi

$A=$ Jumlah Telur yang terparasit

$B=$ Jumlah seluruh telur

(Pabbage dan Tandiabang, 2007).

2) Persentase Jumlah Larva Penggerek Batang yang Muncul (\%)

Jumlah imago yang muncul per pias (Ekor) dihitung setelah imago Trichogramma sp. semuanya mati dengan menggunakan mikroskop atau lup (kaca pembesar).

\section{HASIL DAN PEMBAHASAN}

\section{Persentasi Telur Penggerek Batang Ter- parasitasi}

Hasil penelitian menunjukan bahwa terdapat perbedaan nyata pada perlakuan parasitoid Trichogamma sp. terhadap tingkat parasitasi telur Chilo sacchariphagus terhadap tingkat parasitasi Trichogamma sp.

Tabel 1. Presentasi telur penggerek batang terparasitasi

Perlakuan telur Presentase telurChilo

Trichogamma sp. $\quad$ sacchariphagus (\%)

+100 telur $C$.

sacchariphagus

$\begin{array}{ll}\text { P1 (1 Pias) } & 46,67 \mathrm{a} \\ \text { P2 (2 Pias) } & 77,33 \mathrm{bc} \\ \text { P3 (3 Pias) } & 81,33 \mathrm{bc} \\ \text { P4 (4 Pias) } & 88,33 \mathrm{c} \\ \text { P5 (5 Pias) } & 92,33 \mathrm{c} \\ \text { P6 (6 Pias) } & 89,00 \mathrm{c}\end{array}$

Keterangan : Angka rata-rata pada tiap kolom yang diikuti huruf yang sama menunjukan tidak berbeda nyata menurut Uji Jarak Berganda Duncan pada taraf $5 \%$.

Tingkat parasitasi Trichogamma sp. yang paling efektif pada telur Chilo sacchariphagus adalah pada perlakuan P5 (5 pias) dengan presentase parasitasi 92,23\%, (Tabel 1). Tingkat parasitasi Trichogamma sp. terhadap penggerek batang bergaris termasuk tinggi, sesuai dengan penelitian Rauf (2000) menyatakan bahwa parasitasi Trichogamma sp. dengan tingkat parasitasi $68,4 \%$ hingga $94,8 \%$ termasuk tingkat parasitasi tinggi. Menurut Corrigan \& Laing (1994) bahwa kemampuan reproduksi Trichogramma sp. dapat meningkat atau mengalami penurunan sesuai dengan jenis inang dan jumlah betina dan jantan pada imago Trichogramma sp. 
Pengaruh banyaknya jumlah kelamin jantan dan betina terhadap keberhasilan parasitasi yaitu bila jumlah imago betina lebih besar maka kemampuan reproduksi populasi tersebut tinggi, dan tingkat parasitasi akan tinggi, karena pada imago jantan hanya membuahi tidak melakukan oviposisi. Sehingga pengaruh dari jumlah betina dan jantan imago Trichogamma sp. yang tidak diketahui, maka yang seharusnya dalam 1 pias bisa mencukupi untuk jumlah 100 telur Chilo sacchariphagus akan tetapi pada Chilo sacchariphagus parasitasi yang tinggi pada perlakuan 5 pias dengan jumlah telur Corcyra cephalonica yang terparasitasi Trichogamma sp. 750 butir.

Menurut Knutson (2002), tiap serangga betina Trichogramma sp. mampu mereproduksi 1-5 telur selama hidupnya. Sebelum memarasit atau melakukan oviposisi, imago betina akan melakukan orientasi untuk memilih telur inang yang berkualitas baik dengan cara menyentuhkan antena dan palpus pada telur inang (Yunus et al. 2004). Imago betina hanya akan meletakkan telur pada telur inang yang dianggap layak untuk perkembangan keturunannya. Kualitas telur inang yang kurang baik menyebabkan imago betina enggan meletakkan telur didalamnya sehingga persentase parasitisasi rendah (Godfray, 1994). Tingginya tingkat parasitisasi dari hasil evaluasi menunjukkan keefektifan penggunaan Trichogramma sp. sebagai agen pengendalian hayati.

\section{Presentase Jumlah Larva Penggerek Chilo sacchariphagus yang Muncul}

Berdasarkan hasil analisis anova presentasi jumlah larva penggerek batang tebu bergaris memberikan pengaruh berbeda nyata.
Tabel 2. Persentase jumlah larva penggerek batang yangmuncul

\begin{tabular}{cc}
\hline $\begin{array}{c}\text { Perlakuan telur } \\
\text { Trichogamma sp. } \\
\text { + } 100 \text { telur } \\
\text { C. sacchariphagus }\end{array}$ & $\begin{array}{c}\text { Jumlah larva } \\
\text { C. sacchariphagus } \\
\text { yang muncul (\%) }\end{array}$ \\
\hline 1 Pias (P1) & $26,33 \mathrm{c}$ \\
2 Pias (P2) & $11,67 \mathrm{~b}$ \\
3 Pias (P3) & $9,00 \mathrm{ab}$ \\
4 Pias (P4) & $11,33 \mathrm{~b}$ \\
5 Pias (P5) & $4,33 \mathrm{a}$ \\
6 Pias (P6) & 7,00 ab \\
\hline Keterangan : Angka rata-rata pada tiap kolom \\
yang diikuti huruf yang sama \\
menunjukan tidak berbeda nyata \\
menurut Uji Jarak Berganda \\
Duncan pada taraf 5\%.
\end{tabular}

Persentase jumlah penggerek untuk Chilo sacchariphagus yang muncul paling banyak pada satu pias yaitu $26,33 \%$ dengan tingkat persentase parasitasi $46,67 \%$ (Tabel 1), karena nilai parasitnya rendah sehingga jumlah larva instar-1 yang keluar lebih banyak, sedangkan pada perlakuan 5 pias (P5) jumlah larva yang muncul lebih sedikit karena telur yang terparasit lebih tinggi dari pada perlakuan lainnya. Berdasarkan nilai korelasi 0,586 terdapat hubungan antara presentasi telur terparasitasi dengan jumlah muncul larva penggerek batang yaitu semakin tinggi presentasi telur terparasitasi maka semakin rendah jumlah larva instar-1 yang muncul. Karena keberhasilan larva penggerek batang Chilo saccaripagus tergantung dari ketahanan telur terhadap parasitoid.

Menurut Pabbage dan Tandiabang (2011) gangguan yang terjadi disebabkan oleh beberapa faktor diantaranya yaitu ruang gerak parasitoid tersebut dalam tabung reaksi terbatas dan letak antara kelompok telur inang saling berdekatan sehingga inang tidak terparasit semuanya. Telur inang yang tidak terparasit bisa menjadi larva instar-1 dan bisa menjadi 
telur busuk atau telur yang tidak berkembang menjadi parasitoid atau larva penggerek instar-1.

\section{SIMPULAN}

Berdasarkan hasil penelitian dapat ditarik kesimpulan sebagai berikut :

1. Jumlah telur Trichogramma sp. berpengaruh terhadap tingkat parasitasi dan jumlah larva penggerek batang tebu bergaris (Chilo saccaripagus)

2. Parasitasi penggerek batang tebu bergaris (Chilo saccaripagus) perlakuan 5 pias telur Trichogamma sp. 750 butir telur memiliki jumlah larva terendah rata-rata 4,33 larva dengan persentasi telur yang terparasit $92,23 \%$.

\section{SARAN}

Penelitian mengenai parasitoid telur Trichogramma sp. masih jarang dilakukan, perlu dilakukan pengamatan jumlah telur jantan dan betina pada telur Corcyra cephalonica yang terparasit Trichogamma sp. sebelum penelitian untuk itu diperlukan penelitian lebih lanjut.

\section{UCAPAN TERIMA KASIH}

Kami ucapkan terimakasih kepada PG Rajawali II Unit Puslit Agro (pusat penelitian Agronomi) yang telah mem-berikan fasilitas laboratorium untuk penelitian ini.

\section{DAFTAR PUSTAKA}

Buchori, D., P. Hidayat., A. Meilin., dan B. Sahari. 2010. Species Distribution Of Trichogramma And Trichogrammatoidea Genus (Trichogrammatoidea: Hymenoptera) In Java. Department of Plant Protection, Bogor Agricultural University. J. ISSAAS Vol. 16, No. 1: 83-96.

Ditjenbun (Direktorat Jenderal Perkebunan). 2008-2009. Statistik Perkebunan Indonesia. Jakarta. Departemen Pertanian, Direktorat Jenderal Perkebunan.

Ganeshan, S. 2001. A Guide to the Insect Pests of Sugar Cane in Mauritius. Entomology Department. Mauritius Sugar Industry Research Institute (MSIRI).

Godfray, H. C. J., 1994. Parasitoids. Behavioral and Evolutionary Ecology. Princeton University Press Princ, New Yersey. 473p.

Hafsah, M.J. 2002. Bisnis Gula di Indonesia. Jakarta: Pustaka Sinar Harapan.

Kartohardjono, A. 2011. Penggunaan Musuh Alami Sebagai Komponen Pengendalian Hama Padi Berbasis Ekologi. Balai Besar Penelitian Tanaman Padi Sukamandi. J.Pengembangan Inovasi Pertanian $4(1): 29-46$.

Knutson. 2002. The Trichogramma Manual: A Guide to the Use of Trichogramma for Biological Control with Special Reference to Augmentative Releases for Control of Bollworm and Budworm in Cotton. [serial online] http://entowww.tamu.edu/extensio $\mathrm{n} /$ bulletins/b-

6071.html\#trichogramma januari 2015) 
Meidalima, D., S. Herlinda, Y. Pujiastuti dan C. Irsan. 2012. Pemanfaatan Parasitoid Telur, Larva dan Pupa untuk Mengendalikan Penggerek Batang Tebu. Palembang: Universitas Sriwijaya.

Pabbage dan Tandiabang. 2007. Parasitasi Trichogramma evanescens Westwood (Hymenoptera: Trichogrammatidae) pada Berbagai Tingkat Populasi dan Generasi Biakan Parasitoid terhadap Telur Penggerek Batang Jagung Ostrinia furnacalis Guenée.

- 2011. Parasitasi Trichogramma evanescens Westwood Pada Berbagai Tingkat Populasi Dan Generasi Biakan Parasitoid Terhadap Telur Penggerek Batang Jagung. Seminar Nasional Serealia Balai Penelitian Tanaman Serealia.
Rauf A. 2000. Parasitasi Telur Pengerek Batang Padi Putih, Scirpophaga innotata (Walker) (Lepidoptera : Piralidae) : Saat Terjadi Ledakan di Kerawang pada Awal 1990-an. Bul. Hama dan Penyakit Tumbuhan 12(1):1-10 (2000). ISSN 0854-3836. Jur. HPT, IPB Bogor

Yunus $M$, Shahabuddin, Buchori D, Hidayat P. 2004. Kemampuan Memarasit dan Ciri-ciri kebugaran Trichogramma japonicum Ashmead dari Pertanaman Padi di Sulawesi Tengah. Di dalam: Arifin $\mathrm{M}$ et al., editor. Entomologi dalam Perubahan Lingkungan dan Sosial. Prosiding Seminar Nasional Perhimpunan Entomologi Indonesia (PEI); Bogor, 5 Oktober 2004. Bogor: PEl. hlm 385-396 